\title{
Stability Indicating RP-HPLC Method Development and Validation for Simultaneous Estimation of Montelukast and Bilastine in Bulk and Pharmaceutical Dosage Form
}

\author{
Rajeswari Sunkara ${ }^{1}$, M. Ajitha ${ }^{2}$ \\ ${ }^{1}$ M. Pharmacy Scholar, Department of Pharmaceutical Analysis, Institute of Science and \\ Technology, JNTUH, Hyderabad \\ ${ }^{2}$ Professor \& Head, Deputy Director of Academic Audit Cell - JNTUH \& OIE, Center for \\ Pharmaceutical Sciences, JNTUH, Hyderabad
}

Received: 18-10-2021 / Revised Accepted: 29-11-2021 / Published: 02-01-2022

\begin{abstract}
A simple, Accurate, precise method was developed for the simultaneous estimation of the Bilastine and Montelukast in bulk and Tablet dosage form. Chromatogram was run through Std kromasil 250 x $4.6 \mathrm{~mm}, 5 \mu$. Mobile phase containing Buffer 0.01N Ammonium acetate: Acetonitrile taken in the ratio 70:30 was pumped through column at a flow rate of 1.0 $\mathrm{ml} / \mathrm{min}$. Buffer used in this method was Ammonium acetate buffer. Temperature was maintained at $30^{\circ} \mathrm{C}$. Optimized wavelength selected was $220.0 \mathrm{~nm}$. Retention time of Bilastine and Montelukast were found to be $2.645 \mathrm{~min}$ and $3.797 \mathrm{~min}$. \%RSD of the Bilastine and Montelukast were found to be $1.2 \%$ and $1.7 \%$ respectively. \%Recovery was obtained as 99.74\% and 99.65\% for Bilastine and Montelukast respectively. LOD, LOQ values obtained from regression equations of Bilastine and Montelukast were 0.31, 0.09 and 0.94, 0.26respectively. \%Assay was obtained as $100.88 \%$ and $99.54 \%$ for Bilastine and Montelukast respectively. Regression equation of Montelukast is $\mathrm{y}=25730 \mathrm{x}+4354, \mathrm{y}=$ $20467 x+3190$ of Bilastine. Retention times were decreased and that run time was decreased, so the method developed was simple and economical that it can be adopted in regular Quality control tests in Industries.
\end{abstract}

Key Words: Montelukast, Bilastine, HPLC

\section{INTRODUCTION}

Montelukast is a leukotriene receptor antagonist (LTRA) used for the treatment of asthma and to relieve symptoms of seasonal allergies. Montelukast blocks the action of leukotriene D4 on the cysteinyl leukotriene receptor CysLT1 in the lungs and bronchial tubes by binding to it. Bilastine

is a novel new generation antihistamine. It is a selective histamine $\mathrm{H} 1$ receptor antagonist. Bilastine binds and prevents activation of $\mathrm{H} 1$ receptor, it reduces the development of allergic symptoms due to release of histamine from mast cells. Literature review revealed that there were few analytical methods reported for Montelukast

Address for Correspondence: Rajeswari Sunkara, M. Pharmacy Scholar, Department of Pharmaceutical Analysis, Institute of Science and Technology, JNTUH, Hyderabad.

How to Cite this Article: Rajeswari Sunkara, M. Ajitha. Stability Indicating RP-HPLC Method Development and Validation for Simultaneous Estimation of Montelukast and Bilastine in Bulk and Pharmaceutical Dosage Form. World J Pharm Sci 2022; 10(01): 90-97; https://doi.org/10.54037/WJPS.2022.100109 
and bilastine in RP-HPLC. An extensive literature search didn't reveal any method for simultaneous estimation of Montelukast and Bilastine in API and pharmaceutical dosage form by RP-HPLC. Therefore, an attempt has been made to develop and validate simple, precise, accurate, economical RP-HPLC method as per ICH guidelines for the estimation of Montelukast and Bilastine in Bulk and Pharmaceutical Dosage Form.

\section{MATERIALS AND METHODS}

Chemicals and Reagents: Acetonitrile (HPLC grade), Methanol, Phosphate buffer, Potassium dihydrogen ortho phosphate buffer, Ortho phosphoric acid, Distilled water (HPLC grade) were purchased from Rankem, India. Montelukast and Bilastine combination dosage form(tablet) were purchased from local market. All active pharmaceutical ingredients (APIs) of Montelukast and Bilastine reference standards were procured from Spectrum Pharma labs, Hyderabad, India.

Instruments and Chromatographic Conditions Electronics Balance -Denver, PH meter-BVK enterprises, India, Ultrasonicator-BVK enterprises, WATERS HPLC 2695 SYSTEM equipped with quaternary pumps, Photo Diode Array detector and Auto sampler integrated with Empower 2 Software was used for LC peak integration and Data processing. UV-VIS spectrophotometer PG InstrumentsT60 with special bandwidth of $2 \mathrm{~mm}$ and $10 \mathrm{~mm}$ and matched quartz cells integrated with UV-win 6 Software was used for measuring absorbance of Montelukast and Bilastine solutions. The mobile phase used was Ammonium acetate: Acetonitrile (70:30) at a flow rate of $1 \mathrm{ml} / \mathrm{min}$, samples were analyzed at $220 \mathrm{~nm}$ detector wavelength and at an injection volume of $10 \mu \mathrm{L}$ using Kromasil C18 (4.6 mm x 250mm,5 $\mu \mathrm{m})$ with run time of $6 \mathrm{~min}$.

\section{Method}

Diluent: Based up on the solubility of the drugs, diluent was selected, Acetonitrile and Water taken in the ratio of 50:50.

\section{Preparation of Standard stock solutions:}

$5 \mathrm{mg}$ of montelukast, $10 \mathrm{mg}$ of bilastine was accurately weighed and was transferred into $50 \mathrm{ml}$ volumetric flasks and 3/4th volume of diluent was added to the flask and sonicated for $10 \mathrm{~min}$. Volume was made up with diluent. (100 $\mu \mathrm{g} / \mathrm{ml}$ of montelukast and $200 \mu \mathrm{g} / \mathrm{ml}$ bilastine)

Preparation of Standard working solutions (100\% solution): $1 \mathrm{ml}$ from each stock solution was pipetted out and taken into $10 \mathrm{ml}$ volumetric flask and volume made up with diluent. $(10 \mu \mathrm{g} / \mathrm{ml}$ of Montelukast and $20 \mu \mathrm{g} / \mathrm{ml}$ of Bilastine)

Preparation of Sample stock solutions: 10 tablets were accurately and average weight equivalent to 1 tablet was transferred into a $100 \mathrm{ml}$ volumetric flask, $50 \mathrm{ml}$ of diluent was added and sonicated for $25 \mathrm{~min}$, further the volume was made up with diluent and filtered by HPLC filters $(100 \mu \mathrm{g} / \mathrm{ml}$ of montelukast and $200 \mu \mathrm{g} / \mathrm{ml}$ bilastine)

Preparation of Sample working solutions $(\mathbf{1 0 0 \%}$ solution): $1 \mathrm{ml}$ of sample stock solution was filtered and was transferred to $10 \mathrm{ml}$ volumetric flask and volume was made up with diluent. $(10 \mu \mathrm{g} / \mathrm{ml}$ of Montelukast and $20 \mu \mathrm{g} / \mathrm{ml}$ of Bilastine)

\section{Preparation of Buffer:}

0.1\% Ortho Phosphoric Acid (OPA) Buffer: 1ml of ortho phosphoric acid was taken and was diluted to $1000 \mathrm{ml}$ with water (HPLC grade)

Buffer:0.01N Ammonium acetate: $0.77 \mathrm{gm}$ Ammonium acetate was accurately weighed and in $1000 \mathrm{ml}$ volumetric flask and to it about $900 \mathrm{ml}$ of milli-Q water was added and degassed to sonicate and finally volume was made up with water to get $0.01 \mathrm{~N}$ Ammonium acetate buffer.

\section{Method Validation}

As per ICH guidelines the method was validated and the parameters like Linearity, Specificity, Accuracy, Precision, Limit of Detection (LOD) and Limit of Quantitation (LOQ) were assessed.

Specificity: Checking of the interference in the optimized method. We should not find interfering peaks in blank and placebo at retention times of these drugs in this method. So this method was said to be specific.

Linearity: Stock solutions of Montelukast and Bilastine is taken into 6 different volumetric flasks and diluted to $10 \mathrm{ml}$ with diluents. Linearity solutions are prepared such that 025, 0.5, $0.75,1,1.25,1.5 \mathrm{ml}$.

Accuracy: Preparation of Standard stock solutions: Accurately weighed $5 \mathrm{mg}$ of Montelukast, $10 \mathrm{mg}$ of Bilastine and transferred into $50 \mathrm{ml}$ volumetric flasks, $3 / 4^{\text {th }}$ of diluents was added to these flasks and sonicated for 10 minutes. Flasks were made up with diluents and labeled as Standard stock solution.

Preparation of $50 \%$ Spiked Solution: $0.5 \mathrm{ml}$ of sample stock solution was taken into a $10 \mathrm{ml}$ volumetric flask, to that $1.0 \mathrm{ml}$ from each standard stock solution was pipetted out, and made up to the mark with diluent. 
Preparation of $100 \%$ Spiked Solution: $1.0 \mathrm{ml}$ of sample stock solution was taken into a $10 \mathrm{ml}$ volumetric flask, to that $1.0 \mathrm{ml}$ from each standard stock solution was pipetted out, and made up to the mark with diluent.

Preparation of $150 \%$ Spiked Solution: $1.5 \mathrm{ml}$ of sample stock solution was taken into a $10 \mathrm{ml}$ volumetric flask, to that $1.0 \mathrm{ml}$ from each standard stock solution was pipetted out, and made up to the mark with diluent.

Robustness: Small deliberate changes in method like Flow rate, mobile phase ratio, and temperature are made but there was no recognized change in the result and are within range as per ICH Guide lines. Robustness conditions like Flow minus (0.9 $\mathrm{ml} / \mathrm{min}$ ), Flow plus $(1.1 \mathrm{ml} / \mathrm{min})$, mobile phase minus, mobile phase plus, temperature minus $\left(25^{\circ} \mathrm{C}\right)$ and temperature plus $\left(35^{\circ} \mathrm{C}\right)$ was maintained and samples were injected in duplicate manner. System suitability parameters were not much affected and all the parameters were passed. $\%$ RSD was within the limit.

LOD sample Preparation: $0.25 \mathrm{ml}$ each from two standard stock solutions was pipetted out and transferred to two separate $10 \mathrm{ml}$ volumetric flasks and made up with diluents. From the above solutions $0.1 \mathrm{ml}$ each of Montelukast, Bilastine solutions respectively were transferred to $10 \mathrm{ml}$ volumetric flasks and volume made up with the same diluents.

LOQ sample Preparation: $0.25 \mathrm{ml}$ each from two Standard stock solution was pipetted out and transferred to two separate $10 \mathrm{ml}$ volumetric flasks and made up with diluents. From the above solution $0.3 \mathrm{ml}$ each of Montelukast, Bilastine solutions respectively were transferred to $10 \mathrm{ml}$ volumetric flasks and made up with the same diluents

System suitability parameters: The system suitability parameters were determined by preparing standard solutions of Montelukast (10ppm) and Bilastine(20ppm) and the solutions were injected six times and the parameters like peak tailing, resolution and USP plate count were determined.

The \% RSD for the area of six standard injections results should not be more than $2 \%$.

Assay of Montelukast and Bilastine Combination Dosage Form (BillargicM): Assay of the marketed formulation was carried out by injecting sample corresponding to equivalent weight into HPLC system

\section{RESULTS \& DISCUSSIONS}

Optimization of Chromatographic Conditions: To develop and establish a suitable-HPLC method for simultaneous estimation of Montelukast and Bilastine in Bulk and tablet dosage forms, different preliminary tests were performed and different chromatographic conditions were tested and optimized chromatographic conditions were developed which were given in Table-1. The final analysis was performed by using $70 \% \quad 0.01 \mathrm{~N}$ Ammonium acetate:30\%Acetonitrile, at a flow rate of $1 \mathrm{ml} / \mathrm{min}$, samples were analyzed at $220 \mathrm{~nm}$ detector wavelength and at an injection volume of $10 \mu \mathrm{L}$ using Kromasil C18 (4.6, 250mm, 5 $\mu \mathrm{m})$ with run time of $6 \mathrm{~min}$. The proposed method was optimized to give sharp peaks with good resolution, the optimized chromatogram was obtained as shown in(Figure-2).

\section{Validation:}

Linearity was established at six different concentrations of Bilastine $(15-30 \mu \mathrm{g} / \mathrm{ml})$ and Montelukast $(2.5-15 \mu \mathrm{g} / \mathrm{ml})$ each were injected in duplicate manner. Average areas were determined and linearity equations obtained for Montelukast was $y=20467 x+3190.4$ and of Bilastine was $y=25730 x+4354$. Correlation coefficient obtained was 0.999 for two drugs. The Linearity calibration curves were plotted as shown in Figure-4\&5. Retention time of Montelukast was 4.106 min and Bilastine was $2.875 \mathrm{~min}$. No interfering peaks in blank and placebo were found in this method. So this method holds its specificity.

Three levels of accuracy samples 50\%, 100\%, $150 \%$ were prepared by standard addition method. Triplicate injections were given for each level of accuracy and mean \% recovery was obtained as $100.67 \%$ and $99.65 \%$ for Bilastine and Montelukast respectively was shown in (Table2\&3).

$\%$ RSD for system precision for Bilastine was 1.2\% and for Montelukast was $1.7 \%$. The $\%$ RSD for repeatability for Bilastine was $0.4 \%$ and for Montelukast was $0.9 \%$. The $\%$ RSD for intermediate precision for Bilastine and Montelukast was $1.4 \%$. Since \% RSD is less than 2 the system precision was passed in this method shown in (Table-4).

The LOD and LOQ values were evaluated based on Relative standard deviation of response and slope of the calibration curves. The Detection limit value for Bilastine was 0.31 and for Montelukast was 0.09. The Quantitation limit value for Bilastine was 0.94 and for Montelukast was 0.26 as given in (Table-5). Robustness conditions like Flow minus $(0.9 \mathrm{ml} / \mathrm{min})$, Flow plus $(1.1 \mathrm{ml} / \mathrm{min})$, Mobile 
phase minus (75B:25A), Mobile phase plus (65B:35A), Temperature minus $\left(25^{\circ} \mathrm{C}\right)$ and temperature plus $\left(35^{\circ} \mathrm{C}\right)$ was maintained and samples were injected in duplicate manner. (Table6)

System suitability parameters were not much affected and all the parameters were passed. \%RSD was within the limit. (Table-7).Bilastine and Montelukast pure drug (API) was obtained from Spectrum Pharma research solutions. BillargicM bearing the label claims Montelukast $40 \mathrm{mg}$ and Bilastine 8mg. Assay was performed with the formulation. Average \% Assay for Bilastine and Montelukast obtained was $100.88 \%$ and $99.54 \%$ respectively the result was shown in (Table-8) and the chromatogram of standard drugs and pharmaceutical dosage form were shown in (Figure 6\&7) respectively.

Degradation Studies: Degradation studies were performed with the formulation and the degraded samples were injected. Assay of the injected samples was calculated and all the samples passed the limits of degradation.

\section{CONCLUSION}

A simple, Accurate, precise method was developed for the simultaneous estimation of the Bilastine and Montelukast. Chromatographic conditions used are Kromasil C18 $(4.6,250 \mathrm{~mm}, 5 \mu \mathrm{m})$. Mobile phase 0.01 NAmmonium acetate: acetonitrile in the ratio of 70:30 and flow rate was maintained at $1 \mathrm{ml} / \mathrm{min}$, detection wavelength was $220 \mathrm{~nm}$, column temperature was set to $30^{\circ} \mathrm{C}$. Retention time of Bilastine and Montelukast were found to be $2.875 \mathrm{~min}$ and $4.106 \mathrm{~min}$. \%RSD of the Bilastine and Montelukast were and found to be $1.2 \%$ and $1.7 \%$ respectively. \% Recovery was obtained as 99.74\% and $99.65 \%$ for Bilastine and Montelukast respectively. LOD, LOQ values obtained from regression equations of Bilastine and Montelukast were $0.31,0.09$ and $0.94,0.26$ respectively. \%Assay was obtained as $100.88 \%$ and $99.54 \%$ for Bilastine and Montelukast respectively. Regression equation of Montelukast is $\mathrm{y}=25730 \mathrm{x}+4354, \mathrm{y}=20467 \mathrm{x}+$ 3190 of Bilastine. Retention times were decreased and that run time was decreased, so the method developed was simple and economical that can be adopted in regular Quality control test in Industries.<smiles>CC(C)(O)c1ccccc1CCC(OCC1(CC(=O)O)CC1)c1cccc(/C=C/c2ccc3ccc(Cl)cc3n2)c1</smiles>

Figure-1: Chemical structure of Montelukast

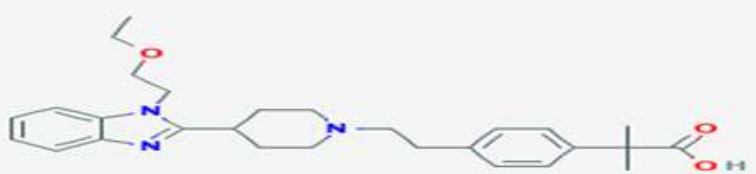

Figure-2: Chemical structure of Bilastine

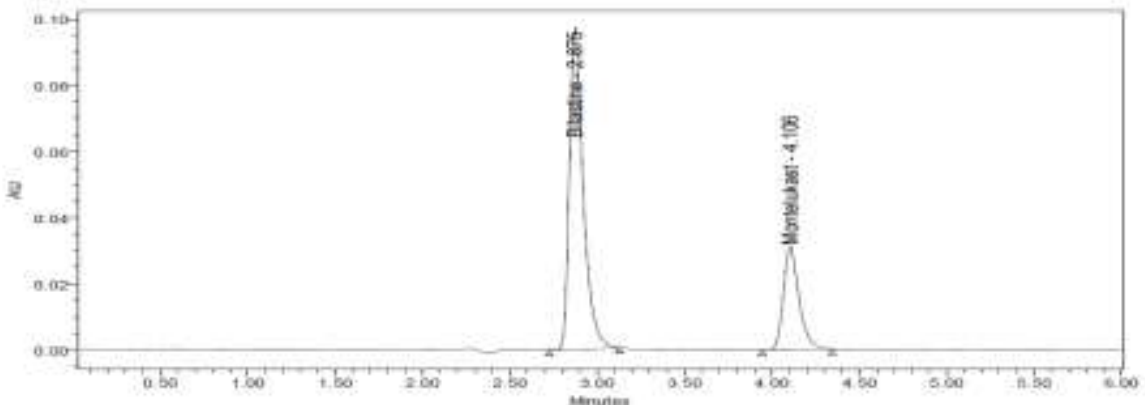

Figure-3: Optimized Chromatogram of Montelukast and Bilastine 
Rajeswari and Ajitha, World J Pharm Sci 2022; 10(01): 90-97

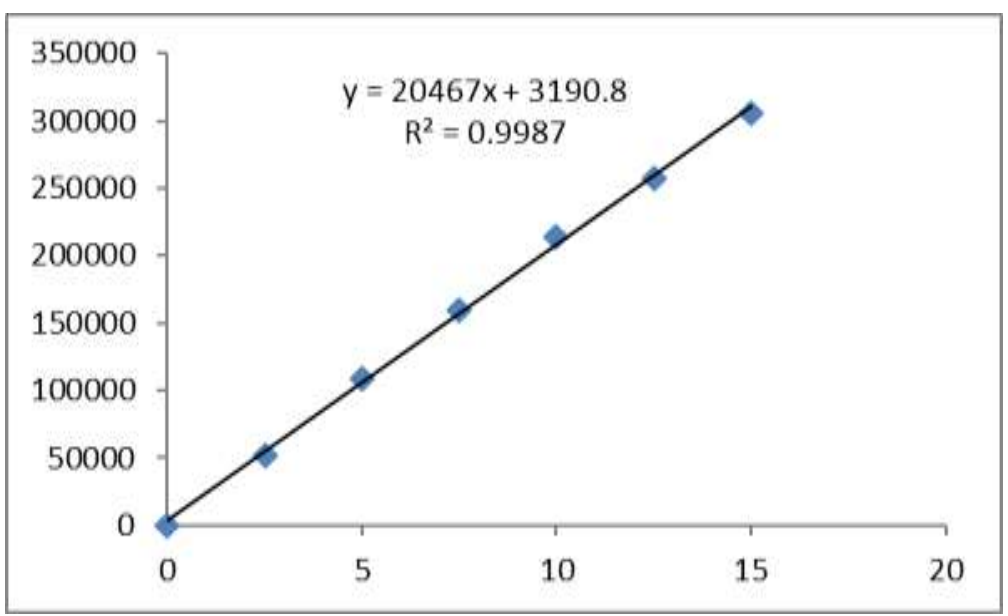

Figure-4: Linearity curve of Montelukast

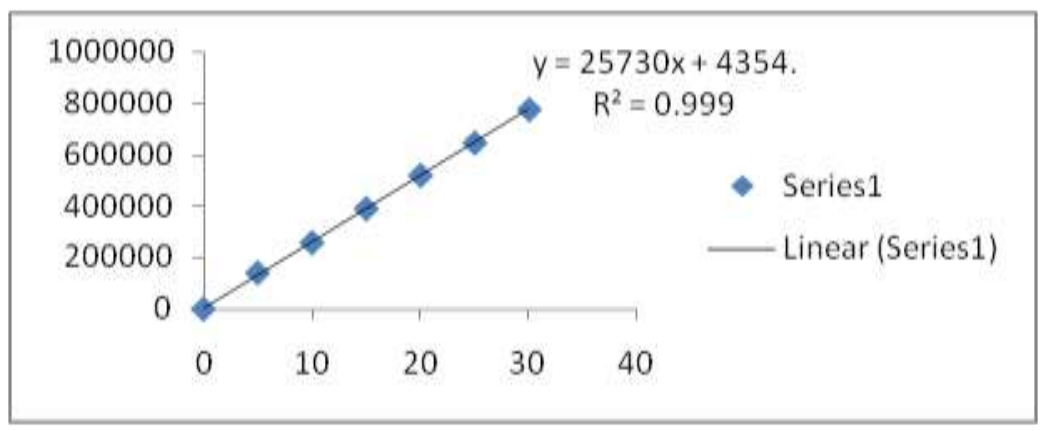

Figure-5: Linearity curve of Bilastine

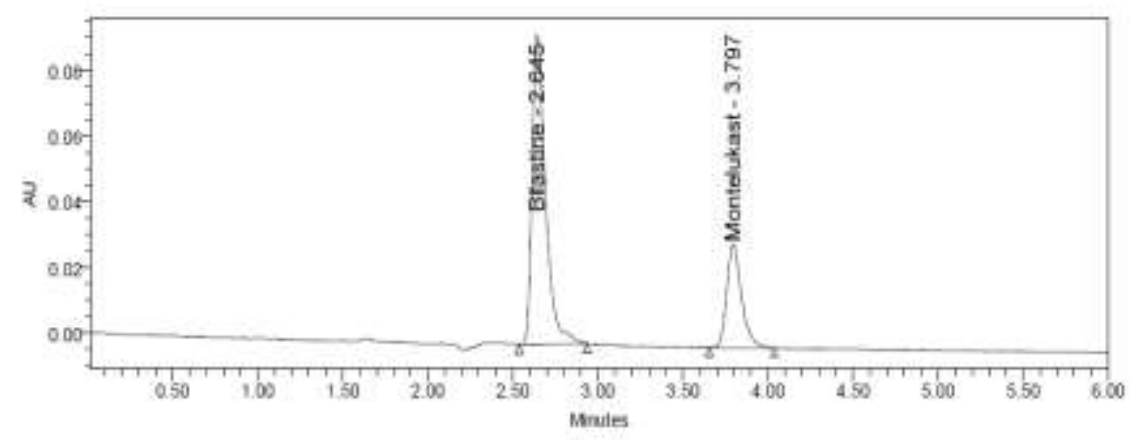

Figure-6 Standard Chromatogram of Montelukast and Bilastine

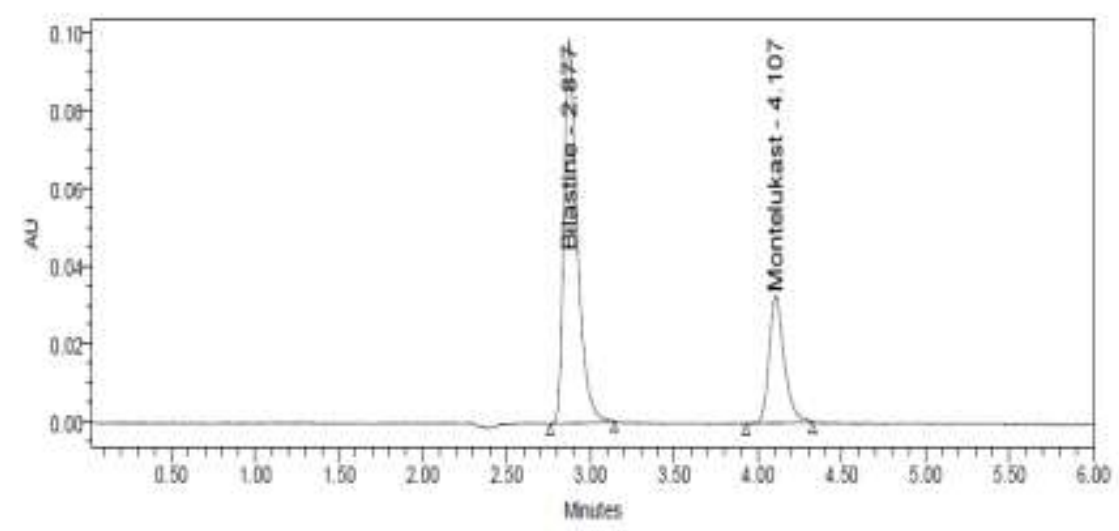

Figure-7 : Sample Chromatogram of working solutions 
Rajeswari and Ajitha, World J Pharm Sci 2022; 10(01): 90-97

Table-1: Optimized Chromatographic Conditions

\begin{tabular}{|l|l|}
\hline Parameters & Conditions \\
\hline RP-HPLC & $\begin{array}{l}\text { WATERS HPLC SYSTEM equipped with quaternary pumps with PDA } \\
\text { detector }\end{array}$ \\
\hline Mobile phase & $70 \% 0.01 \mathrm{~N}$ Ammonium acetate:30\% Acetonitrile \\
\hline Flow rate & $1 \mathrm{ml} / \mathrm{min}$ \\
\hline Column & Kromasil C18(4.6x250mm,5 $\mu \mathrm{m})$ \\
\hline Detector wavelength & $220 \mathrm{~nm}$ \\
\hline Column temperature & $30^{\circ} \mathrm{C}$ \\
\hline Injection volume & $10 \mu \mathrm{L}$ \\
\hline Run time & 6 min \\
\hline Diluent & Water:Acetonitrile(50:50) \\
\hline Retention Time & Bilastine 2.875 min and Montelukast 4.106 min \\
\hline Theoritical plates & Bilastine -6605, Montelukast- 10640 \\
\hline
\end{tabular}

Table-2: Accuracy results of Bilastine

\begin{tabular}{|c|c|c|c|c|}
\hline $\begin{array}{l}\% \\
\text { Level }\end{array}$ & $\begin{array}{l}\text { Amount Spiked } \\
(\mu \mathrm{g} / \mathrm{mL})\end{array}$ & $\begin{array}{l}\text { Amount } \\
\text { recovered } \\
(\mu \mathrm{g} / \mathrm{mL})\end{array}$ & \% Recovery & $\begin{array}{l}\text { Mean } \\
\text { \%Recovery }\end{array}$ \\
\hline \multirow{3}{*}{$50 \%$} & 10 & 9.9 & 98.8 & \multirow{9}{*}{$100.57 \%$} \\
\hline & 10 & 10.0 & 99.7 & \\
\hline & 10 & 9.9 & 99.0 & \\
\hline \multirow{3}{*}{$100 \%$} & 20 & 20.0 & 99.8 & \\
\hline & 20 & 19.9 & 99.5 & \\
\hline & 20 & 20.0 & 100.2 & \\
\hline \multirow{3}{*}{$150 \%$} & 25 & 25.1 & 100.6 & \\
\hline & 25 & 25.1 & 100.6 & \\
\hline & 25 & 24.9 & 99.4 & \\
\hline
\end{tabular}

Table-3 Accuracy results of Montelukast

\begin{tabular}{|c|c|c|c|c|}
\hline \% Level & $\begin{array}{l}\text { Amount Spiked } \\
(\mu \mathrm{g} / \mathrm{mL})\end{array}$ & $\begin{array}{l}\text { Amount } \\
\text { recovered } \\
(\mu \mathrm{g} / \mathrm{mL})\end{array}$ & \% Recovery & $\begin{array}{l}\text { Mean } \\
\text { \%Recovery }\end{array}$ \\
\hline \multirow{3}{*}{$50 \%$} & 5 & 5.01 & 100.23 & \multirow{9}{*}{$99.65 \%$} \\
\hline & 5 & 4.96 & 99.19 & \\
\hline & 5 & 4.98 & 99.58 & \\
\hline \multirow{3}{*}{$100 \%$} & 10 & 9.90 & 99.02 & \\
\hline & 10 & 10.00 & 100.01 & \\
\hline & 10 & 9.93 & 99.25 & \\
\hline \multirow{3}{*}{$150 \%$} & 15 & 15.28 & 101.86 & \\
\hline & 15 & 14.75 & 98.34 & \\
\hline & 15 & 14.90 & 99.36 & \\
\hline
\end{tabular}


Rajeswari and Ajitha, World J Pharm Sci 2022; 10(01): 90-97

Table-4 Precision results of Montelukast and Bilastine

\begin{tabular}{|l|l|l|l|l|}
\hline S.No & \multicolumn{2}{|c|}{ Montelukast } & \multicolumn{2}{c|}{ Bilastine } \\
\hline & Repeatability & $\begin{array}{l}\text { Intermediate } \\
\text { precision }\end{array}$ & Repeatability & $\begin{array}{l}\text { Intermediate } \\
\text { precision }\end{array}$ \\
\hline 1. & 201638 & 195046 & 515370 & 519363 \\
\hline 2. & 199495 & 202393 & 518685 & 518398 \\
\hline 3. & 202115 & 197206 & 517073 & 500197 \\
\hline 4. & 204074 & 197155 & 519927 & 514083 \\
\hline 5. & 203530 & 201061 & 521762 & 510236 \\
\hline 6. & 204207 & 198001 & 520117 & 506472 \\
\hline Mean & 202510 & 198477 & 518822 & 511458 \\
\hline S.D & 1809.6 & 2734.0 & 2303.7 & 7358.1 \\
\hline \%RSD & 0.9 & 1.4 & 0.4 & 1.4 \\
\hline
\end{tabular}

Table-5 LOD and LOQ values of Montelukast and Bilastine

\begin{tabular}{|c|c|c|}
\hline Molecule & LOD & LOQ \\
\hline Bilastine & 0.31 & 0.94 \\
\hline Montelukast & 0.09 & 0.26 \\
\hline
\end{tabular}

Table-6 Robustness values of Montelukast and Bilastine

\begin{tabular}{|c|l|c|c|}
\hline S.no & Condition & \% RSD of Bilastine & $\begin{array}{c}\text { \%SD } \\
\text { Montelukast }\end{array}$ \\
\hline $\mathbf{1 .}$ & Flow rate(-) $0.9 \mathrm{ml} / \mathrm{min}$ & 0.6 & 1.6 \\
\hline $\mathbf{2 .}$ & Flow rate(+)1.1ml/min & 1.7 & 1.3 \\
\hline $\mathbf{3 .}$ & Mobile phase(-)75B:25A & 1.4 & 0.5 \\
\hline $\mathbf{4 .}$ & Mobile phase(+)65B:35A & 0.9 & 0.7 \\
\hline $\mathbf{5 .}$ & Temperature(-)250 & 1.7 & 1.2 \\
\hline $\mathbf{6 .}$ & Temperature $(+) 35^{0} \mathrm{C}$ & 0.9 & 1.6 \\
\hline
\end{tabular}

Table-7 System suitability parameters for Bilastine and Montelukast

\begin{tabular}{|c|l|l|l|l|l|l|l|}
\hline S.no & \multicolumn{3}{|c|}{ Bilastine } & \multicolumn{3}{|c|}{ Montelukast } \\
\hline Inj & RT(min) & $\begin{array}{l}\text { USP } \\
\text { plate } \\
\text { count }\end{array}$ & Tailing & RT(min) & $\begin{array}{l}\text { USP } \\
\text { plate } \\
\text { count }\end{array}$ & Tailing & RS \\
\hline $\mathbf{1 .}$ & 2.645 & 6115 & 1.52 & 3.797 & 9576 & 1.30 & 7.6 \\
\hline $\mathbf{2 .}$ & 2.691 & 6349 & 1.52 & 3.865 & 9977 & 1.26 & 7.9 \\
\hline $\mathbf{3 .}$ & 2.839 & 6680 & 1.47 & 4.067 & 10784 & 1.31 & 8.1 \\
\hline $\mathbf{4 .}$ & 2.851 & 6161 & 1.50 & 4.091 & 10363 & 1.29 & 7.9 \\
\hline $\mathbf{5 .}$ & 2.872 & 6605 & 1.52 & 4.101 & 10640 & 1.31 & 7.9 \\
\hline
\end{tabular}

Table-8 Assay results of Bilastine and Montelukast

\begin{tabular}{|l|c|c|}
\hline S.no & Bilastine (\% Assay) & Montelukast (\%Assay) \\
\hline 1. & 100.21 & 99.11 \\
\hline 2. & 100.86 & 98.06 \\
\hline 3. & 100.54 & 99.34 \\
\hline 4. & 101.10 & 100.31 \\
\hline $\mathbf{5 .}$ & 101.46 & 100.04 \\
\hline 6. & 101.14 & 100.37 \\
\hline Avg & 100.88 & 99.54 \\
\hline Stdev & 0.45 & 0.89 \\
\hline \%RSD & 0.4 & 0.89 \\
\hline
\end{tabular}


Table-9 Degradation data of Bilastine and Montelukast

\begin{tabular}{|l|l|l|l|l|l|l|}
\hline S.no & \multicolumn{2}{|c|}{ Bilastine } & \multicolumn{2}{c|}{ Montelukast } \\
\hline & $\begin{array}{l}\text { Degradation } \\
\text { Condition }\end{array}$ & $\begin{array}{l}\text { \% Drug } \\
\text { Degraded }\end{array}$ & $\begin{array}{l}\text { \%Drug } \\
\text { Remained }\end{array}$ & $\begin{array}{l}\text { Degradation } \\
\text { Condition }\end{array}$ & $\begin{array}{l}\text { \%Drug } \\
\text { Degraded }\end{array}$ & $\begin{array}{l}\text { \% } \\
\text { Remained }\end{array}$ \\
\hline 1. & Acid & 5.96 & 94.04 & Acid & 5.49 & 94.51 \\
\hline $\mathbf{2 .}$ & Alkali & 4.60 & 95.40 & Alkali & 4.47 & 95.53 \\
\hline $\mathbf{3 .}$ & Oxidation & 3.85 & 96.15 & Oxidation & 3.77 & 96.23 \\
\hline $\mathbf{4 .}$ & Thermal & 2.64 & 97.36 & Thermal & 2.30 & 97.70 \\
\hline $\mathbf{5 .}$ & UV & 1.26 & 98.74 & UV & 1.48 & 98.52 \\
\hline 6. & Water & 0.71 & 99.29 & Water & 0.89 & 99.11 \\
\hline
\end{tabular}

\section{REFERENCES}

1. https://go.drugbank.com/drugs/DB00471

2. https://go.drugbank.com/drugs/DB11591

3. R. Mohan Raj*, A. S. K. Sankar et al.., Analytical Method Development And Validation For Simultaneous Estimation Of Bilastine And Montelukast Sodium By Uv Spectrophotometry, World Journal of Pharmacy and Pharmaceutical Sciences, Vol 10, Issue 1, 2021.

4. R. M. Singh, p. K. Saini et al.., Development and validation of a RP-HPLC method for estimation of montelukast sodium in bulk and in tablet dosage form, indian J. Pharm. Sci., 2010, 72 (2): 235-237.

5. N. S. Rana, K. S. Rajesh et al.., Development and Validation of RP-HPLC Method for the Simultaneous Estimation of Montelukast Sodium and Ebastine in Tablet Dosage Form, Indian J Pharm Sci. 2013 Sep-Oct; 75(5): 599-602.

6. Suparna S. Tandulwadkar, Snehal J. More et al..., Method Development And Validation For The Simultaneous Determination Of Fexofenadine Hydrochloride And Montelukast Sodium In Drug Formulation Using Normal Phase High-Performance Thin-Layer Chromatography, International Scholarly Research Notices 2012 .

7. Peethala Prathyusha, Raja Sundararajan. Uv Spectrophotometric Method For Determination Of Bilastine In Bulk And Pharmaceutical Formulation, Research J. Pharm. and Tech 2020; 13(2):933-938

8. R. M. Bankar, D. B. Patel et al.., Rp-Hplc Method For Simultaneous Estimation Of Montelukast Sodium And Desloratadine In Combined Dosage Form, 2013

9. Sutirtho Mukhopadhyay 1, Kiran Kadam, Laxman Sawant et al.., Simultaneous determination of related substances of Montelukast and hydrochlorothiazide in tablet dosage form by using reversed phase high performance liquid chromotographic method, J Pharm Bioallied Sci 2011Jul;3(3):375-83. 